\title{
REGIONAL CONSTITUENT OF INTEGRATION PROCESS OF UKRAINE IN THE EUROPEAN SPACE
}

The complex of problems associated with the Ukraine's entry into the European space through regions development is investigated in the article. The logistics of export-import operations with European countries in the regional context is analyzed. Measures to enhance Ukraine's European integration processes are offered.

Keywords: region, European space, integration, EU-Ukraine economic and social development.

DOI: $10.21272 / \mathrm{mmi} .2017 .4-21$

Problem formulation. Ukraine's integration strategy into the European Union (EU) is a complex socioeconomic, political and legal problem. Its implementation requires an objective social and political base of support for the European integration course expansion. This explains the need to analyze and study the key issues associated with the institutional changes in the context of promoting the European integration development at the level of business associations, trade unions, civil society organizations, etc. In this case, it acquires a special urgency in the formation problem of active Ukraine regions involvement in the formation and the integration policy implementation into EU structures mechanisms.

Ukrainian Government, Parliament and the public and business must work together to ensure the regional logistics of effective integration with the EU revitalization, to identify promising areas and ensure maximum regional opportunity use, promote regions self-development in an integrated campaign for Ukraine's integration into the European space in the experience of EU member states light.

Analysis of recent studies and publications and the allocation unresolved general problem parts. Different foreign economic Ukraine's integration policy aspects into the European space formation devoted to the works: Turchin Y. [1], Datzkbv I. [2], Novitzky V., Shnurkov A. [3], Mykula N. [4], Kuharskaya N. [5], Sidenko V. [6].

The main content of these scientists' works is devoted to the foreign economic activity in the area of trade problems and prospects, the free trade zones and free trade zones creation, the competitiveness of domestic producers' problems on the European markets. Another series of problems connected with the study and the market economy adaptation in Europe to the Ukrainian practice realities. However, the complex problems associated with the Ukraine's entry into the European space through the introduction, considering regions development on the basis of a European is not studied fully.

According to the Action Plan "Ukraine-EU" our country must:

1) "continue the progress made in establishing a full-fledged market economy, including the pricing, subsidies and building the legal framework that ensures fair competition control;

2) advance further in the gradual approximation of legislative and regulatory framework to EU standards and ensure its effective implementation;

3) improve the investment climate, which includes transparency, predictability and regulation and the application of these rules simplification" [6].

Another condition is that the EU market - Progress in macroeconomic stabilization and growth. It includes a requirement to strengthen the independence of the NBU, including, if necessary, amendments to the "On National Bank" Ukraine Law to bring it into line with EU standards, as well as to reform the taxation system 
and the pension system. Despite the European Union's policy statement that the "European Neighborhood Policy" and the Action Plan are aimed at rapprochement between the enlarged EU and neighboring countries, they are, in essence, is the policy of preventing the next wave of EU expansion and the elimination from the agenda or postponing the question of Ukraine's accession to EU.

However, according to the European Commission "Wider Europe - Neighborhood countries" to "promote regional and interregional cooperation for the Western New Independent States, to which the EU does and Ukraine on the future eastern external the EU border already exists closer regional economic cooperation, focused on traditional areas of trade and investment. At the same time, promotion of regional political cooperation and / or economic integration has not yet been turned into one of the arms of the EU's policy on the Western New Independent States [7, p. 91].

Approved concept of the Eastern Partnership, which deals with Ukraine, Moldova, Georgia, Azerbaijan, Armenia and Belarus, if it wants to take part, establishes a positive, accumulated by our country and the European Union for the duration of the Agreement on Partnership and Cooperation, highlights the Ukraine and other CIS countries in a separate block of EU foreign policy, not turning Ukraine into a "gray" area.

The purpose of this article is to study the experience of the countries of the "young members of the EU" and they received results, the socio-oriented criteria for Ukraine's regions integration into the European space implementation.

Statement of the base material. Mastering basic elements of a common set of EU legislation (acquis communautaire) facilitates further into the EU. However, it should be noted that the fact that the Association Agreement has a limited impact on the institutional procedures initiated accession to the EU, which is much more important is the formal recognition of the European Union "Candidate" status, and feeding the country a formal request for membership. In this case the procedure of accession to the EU, given its complexity and importance, can last much longer time (in practice, 10 or more years).

The mechanism for the program priorities implementation are the annual action plans (Figure 1), which are an integral part of the Work Plan on adaptation of Ukrainian legislation to EU legislation.

Designed based on the experience of the regional policy of the European Union and the Central and Eastern European countries (CEE), the Law of Ukraine "On Stimulation regions development" [6] is designed to favor overcoming depression some Ukrainian territories, the creation of conditions for their rapid socio-economic development. At the same time, despite the adoption of a number of important programs and documents in Ukraine has not yet created the necessary prerequisites for our country's accession to the EU.

Developed taking experience of the regional European Union policy and the Central and Eastern European countries (CEE), the Law of Ukraine "On the stimulation of the regions development" [8] is designed to favor the overcoming of the depressiveness of certain Ukrainian territories, creating conditions for their dynamic socioeconomic development. At the same time, despite the number of important programs and documents adoption, Ukraine still does not have real prerequisites for our country's accession to the EU.

As is known, the current gaining membership procedure in the European Union is based on Article 49 of the EC Treaty (which is almost unchanged reproduces Article I-57 of the future EU Constitutional Treaty), which contains two requirements for the candidate countries for accession: to be geographically a European state, and to be a country with established democracies.

At the European Council in Copenhagen in 1993 the State Heads and Government adopted the basic, so-called "Copenhagen" criteria, which should be used for the countries' candidate evaluation for accession to the EU. At the meeting it was formulated by the political and economic demands. From the candidate countries politician standpoint demands a need to create stable institutions guaranteeing democracy, the legal society, human rights and respect and the national minorities rights protection. Economic criteria for candidate countries are evidence of the functioning market economy and ability to compete in the EU internal market existence as well as the ability to assume the obligations associated with the entry into the European Union (referring to the practical acquis communautaire application). 


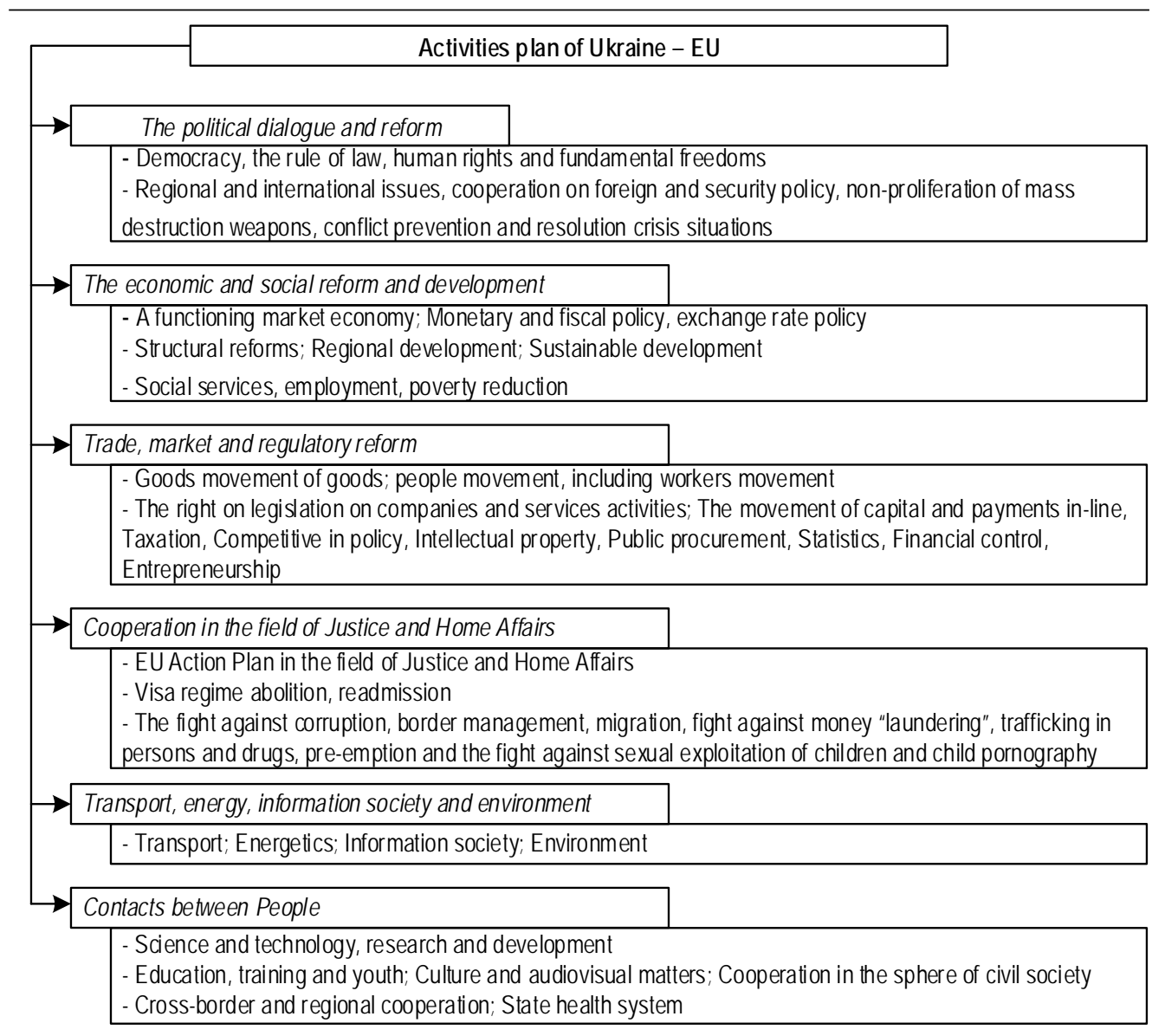

Figure 1 - Activities plan of Ukraine-EU (compiled by the author)

The main economic criterion is an efficient logistics market evidence. According to the European Commission to create such logistics it is necessary to ensure the existence of [3, p.92]:

- the supply and demand balance, ensuring market forces and price interaction and trade liberalization;

- absence of significant barriers to "market entry" (new companies' creation) and "exit from the market" (bankruptcy);

- the legal system that protects property rights;

- macroeconomic stability, including price stability, a balanced budget and balance of payments;

- broad public support for economic policy;

- the financial sector stability, which should be developed enough to take the savings and invest them productively in the economy.

Another economic criterion, namely the country's ability to withstand competition within the EU. In this case, it is necessary to take into account more factors. You have to properly anticipate and assess the development in the future. The main question is whether the Ukrainian enterprises can adapt to the competition conditions in the EU and contribute to the existing this adaptation environment. In this analysis, 
the European Commission the EU considers the following factors [3, p.98]:

- the functioning market economy existence with a sufficient macroeconomic stability degree, which ensures the economic agents' ability to make decisions in stability and predictability terms;

- a sufficient number available production factors, including labor, production capacity and infrastructure (energy, telecommunications, transport, etc.);

- Ukrainian enterprises need to invest and improve their efficiency and, consequently, improve Ukraine's competitiveness, and take scale economies advantage, which will be able to gain access to the single market. To do this they need to have access to cheap capital, skilled labor force and innovation;

- the government and legislation ability affect the competition through trade, competition policy, state subsidies, support for small and medium-sized enterprises;

- the involvement degree in the EU economy prior to accession. This applies both to the trade volume, and the goods range involved in the Ukrainian goods exchange with the European Union. The stronger Ukraine will be integrated into the EU, the less time and resources required in the future to adapt Ukraine to the EU accession. This also applies to investment and the similar legislation adoption;

- small and average enterprises participation in the national economy. This criterion should be considered because these businesses get more benefits from free access to the market, and because large firms dominance could indicate a reluctance to increase competition.

One of the most important indicators is the economic integration with the EU degree. Inside the European Union market is defined in Article 14 of the Agreement on partnership and cooperation as an area without internal frontiers in which the free goods movement is guaranteed, services, capital and labor (the so-called "four freedoms") [9]. Effective implementation and these freedoms application requires not only commitment to the important the single market principles, such as, for example, mutual recognition of national legislations but also the effective common rules application, for example, in the safety area, the environment, intellectual property, which are important for the single structure creation in which the national economy functioning.

The internal market is the key to economic integration. It is based on the free market, in which competition and economic and social cohesion play an important role. At the same time, special attention should be paid to the regional development problems: competitiveness and demand for profiling industries products; expanding the economic potential and opportunities for import substitution important products types; the working population employment; attracting investments to the real economy and housing; social development, including Housing and environmental conservation; increase revenues and balanced regions and municipalities budgets. As a result of significant differences in climatic, economic and other conditions in the Ukrainian regions, reproductive processes in these systems are unique. Their effectiveness depends on structural, financial, investment, foreign trade, social and other policies. The balance of these aspects in regional policy is a prerequisite for a comprehensive and proportional the country's economy development.

To integrate into the European Community, Ukraine should achieve figures that are defined by the Maastricht Treaty to the candidate countries [10, p.75]: its currency stability; reducing inflation to $2 \%$ per year; the budget deficit to $3 \%$ of GDP; public debt - up to $60 \%$ of GDP; Production per capita GDP - more than 10 thousand US dollars. That is, the main problems faced by the real economy sector enterprises, is the increase rate in output, labor productivity, products competitiveness, the wages level. In addressing these issues should be oriented managing regional economy sector mechanism.

The criteria for the state's readiness for EU membership are considered not only its economic development level, but the EU and its own interest in the markets of various countries. So, an interesting experience for Ukraine joining the EU some countries.

Preparation for the accession of 10 countries (Cyprus, Latvia, Lithuania, Malta, Poland, Slovakia, Slovenia, the Czech Republic and Estonia) for more than ten years in the EU. Taking into account the 
transitional provisions in some sectors and areas of the process for the EU-10 it is fully completed in 2009. During the preparation for the new accession countries have successfully transformed their economies from the planned in-functioning market (it is not fully applied to Malta and Cyprus). During the immediate preparation for the entry and after the pace EU-10 growth is 1.7 times higher than those EU-15 economic indicators. Already in 1997-2005. GDP per capita in the EU-10 rose from 44.3 to $52.1 \%$ of the EU-15 level. The annual growth rate in real wages over the last ten years in the EU-10 were 3.5 times higher than in the EU-15. In addition, the EU-10 countries have significantly improved human development indices (HDI) by the UNDP estimates, especially Latvia, Lithuania, Estonia, Slovakia and Hungary [9]. According to the European Commission experts, the adoption in 2004-10 new member countries in the European Union cost $5.3 \mathrm{bln}$. Euro. Only in 2005 and 2006 to ensure the successful integration of these countries into the EU structures has been spent 10.4 and 12 billion euro, respectively [8]. The total cost of the expansion in 2000-2006. It amounted to 80 billion euros, of which 16 billion for the common agricultural policy, 47 billion - on the financing through the structural funds and the remainder - on administration and external and internal political events. The EU-10 payments to the EU-15 budget are limited to a maximum GDP value of $1.2 \%$. Currently, the standard member countries' payments value is $1.15 \%$ of GDP. During the years 2000-2006 EU Member States contributions to the Community budget to the less prosperous regions and social groups constituted a third of the budget, or 213 billion Euro [11, p. 97].

In addition, structural changes and improving the technological level of the national the EU-10 economies would have been impossible without solid foreign investment. In 2004, the accumulated foreign direct investment volume reached 191 billion euros, or 40\% corresponding to the total country's GNPThe new EU members. The foreign affiliates share in applied research and development in the Czech Republic, Hungary, Poland and Slovakia has increased from 9.3 to 41.3\% in 1993-2003 [12].

Regarding accession 1 January 2007 the EU-25, Romania and Bulgaria, the situation is more complicated: these countries are not quite ready for full membership. Even being already the EU members, they must continue to comply with all the conditions that normally require from candidates, namely the Romanian and Bulgarian goods number will not have access to the European market; Romanian and Bulgarian citizens will be more powerless in the labor the EU market than those in the EU-25 countries; with inefficient use of European farm subsidies to these countries will be deprived to the rights most of the allocated sums from the EU budget; in the conflict event 25 countries have the right not to recognize decisions by Bulgarian and Romanian courts. In addition, the two countries should also continue reforms implementation in the legal and legislative sphere, to continue the negotiations with the EU on a number of economic issues and efforts to combat corruption. Every six months, they have to report on progress to the European Commission. This monitoring mode is applied in order to ensure that Romania and Bulgaria continue to reforms initiated. This fully applies to Croatia. Although, in fairness, it should be noted that the economic reforms in Croatia are more effective than in these last two countries.

With these two countries entry, the European Union has acquired in a sense and a new quality. And the rest of the country, and are officially recognized as candidates for accession (this number includes Ukraine) and are just going to be, will be integrated into the EU is quite other conditions.

In addition to achieving "Copenhagen" criteria for accession to the EU Ukraine, two conditions must be met to achieve the European level:

- the technology and labor productivity development;

- well-being and living standards.

However, today in Ukraine reforms are still far from European standards development. Since independence, machinery decreased by 3 times, light industry - by 8 times, the electronic industry - more than 100 times. High European standard technologies is impossible without science funding priority. However, the budget spending on science in the years of independence have fallen by more than 30 times. During the reform years living standard has decreased by 10-12 times in Ukraine. Ukraine, according to 
the UN, was on the 139 place out of 160 analyzed countries. Life standard as an indicator of the wealth ratio of the poorest population is $10 \%$ to the same rich population number in the European Union is 6:1, in the United States - 9-10:1, in Russia 14,5:1, while in Ukraine - 20-40:1 [13]. According to the Economic Forecasting Institute of NASU scientists, Ukraine desirable ratio is no more than 4-5:1. The increase in the ratio over 10:1 indicates the social instability in society, a sharp polarization, opposition groups hostile environment for sustainable economic development. A significant society differentiation by income is not conducive to the middle class and civil society formation.

According to researchers in poorer EU countries account for 8\% in the US - 13\% [4, p.94], the middle class is estimated to be $60-70 \%$, providing a stable and sustainable society development.

As known, there are so-called economic threshold that must overcome the pretender country at the entry time. In numbers, this means that the share of GDP per capita of a country should be at least 25$35 \%$ of the GPD share per capita the most developed EU countries, such as Germany and France. This figure in Ukraine in 2007 is amounted to $\$ 3,000$. To achieve the level of 10 thousand dollars, which is the economic threshold today, at the annual rate growth of at least $8 \%$, we need $25-27$ years.

International trade agreements and efficient internal business environment each region are important economic growth and development components, but by themselves they do not provide any real benefit. The benefits realized from trading companies in the region who use the available opportunities. In this context, analysis (Figure 2) showed that, the foreign trade in services with the EU in East macro-region areas (Cherkasy, Kharkov, Sumy, Kirovograd and Zaporozhye regions) - greatly increased -2.7 times, but mainly due to the services import (by 5.7 times). The predominance of services imports over exports is observed in all areas of East macro-region (except Kirovohrad region). "Leader" is Kharkiv (USD -81.8 million.) and Sumy (-80.8 million. Dollars.) Area. Out the 12 regions of West macro-region (Chernihiv, Chernivtsi, Khmelnytsky, Ternopil, Rivne, Lviv, Kiev, Ivano-Frankivsk, Zacarpattia, Zhytomyr, Volyn, Vinnitsia regions) - 9-export of services prevails over imports, and all Southern macro-region areas (Kherson, Odesa and Mykolaiv regions) greater provision of services EU country than their consumption. In the capital of Ukraine imports services from the EU-15 is even more significant. There is a growing services export in the EU-10 countries from almost all Ukrainian regions. Exceptions are Poltava, Transcarpathian regions. However, the negative foreign trade balance in services with the EU-10 countries is present in 12 Ukrainian regions. "Leader" is a negative Vinnytsia region balance (USD -52.9 million.).

Analysts believe [5], the statistics Ukrainian exports and imports volumes consistently underestimated: exports - by $10-22 \%$ and imports - by $15-30 \%$, indicating that the trend of illegal capital exports by manipulating the export prices and the large-scale import operations use for the illegal export capital and tax avoidance through the deliberate goods customs value understatement. In the service sector there are big trends conceal the real volume of transactions, taking into account their "invisibility". For example, in Portugal about 100 thousand people work illegally during the season. Ukrainian citizens, and only 45 thousand have a work permit. Poland, the Czech Republic, Slovakia and Hungary illegally employ about 1 million people, mostly western Ukraine border regions residents.

In order to form the European standards implementation foundations in the field of trade, directly in the Ukrainian regions, is expedient to introduce such measures, analyze market opportunities and requirements to be followed for the implementation of these features (provide information), for example, in relation to EU markets for products for which eliminated tariffs under the free trade zone; analyze changes in relevant sectors should be implemented over time in order to ensure the trade maintenance with the EU or within the Ukraine after bringing Ukrainian legislation in full compliance with EU standards; strategic planning in order to take advantage of opportunities that arise in the short, medium and long term; carry out the necessary investments in the regions for the enterprises revitalization to meet the domestic and European markets' needs; provide ongoing monitoring and support opportunities offered for example, sending information to interested organizations reports on public contracts offered in the EU. 


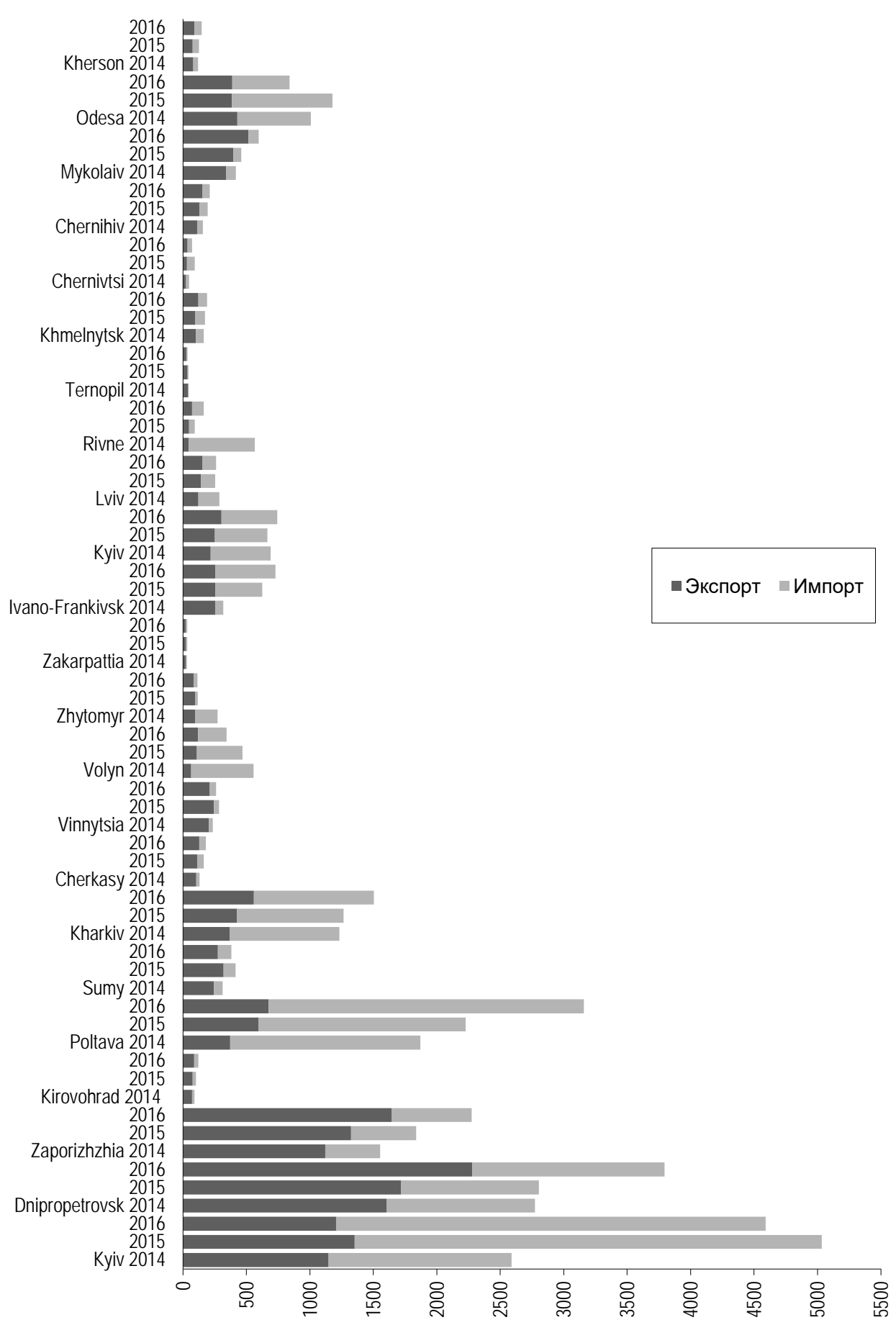

Figure 2 - Foreign wares commerce by Ukrainian regions, $\mathrm{mln}$. \$ 
Conclusions. Thus, logistics European integration for Ukraine and the EU is a challenge. Moreover, the EU should develop a clear, understandable strategy on Ukraine (this is challenge for the EU, which makes up for it Ukraine) and Ukraine to verify their ability to not only declare their European integration, but also to demonstrate the ability of European integration course implementation and meet the criteria for EU membership, based on European experience implementing logistics and the country's socio-economic self-development.

To be effective, Euro-integration with progressive positive impact on Ukraine needs, first of all, the domestic efforts consolidation to ensure the conditions for a stable democratic development of Ukrainian society, the formation of a competitive national economy - the basis of mutually beneficial cooperation and partnership. In addition, Ukraine will be the country that implements the European values, developing the process of European unification. Therefore, further research should be focused on what is directly the regions should develop, plan and implement the strategies needed to use their regional strengths and opportunities.

1. Історія міжнародних відносин (від Стародавнього світу до початку XX ст.) : навч. посіб. / Я.Б. Турчин, Р.Б. Демчишак, Т.І.Плазова ; Нац. ун-т «Львів. політехніка». - Львів : Вид-во Львів. політехніки, 2013.- 139 с.

2. Дацків І.Б. Україна як учасник міжнародної інвестиційної діяльності: історичний аспект / І.Б. Дацків, В.В. Маслій // «Гілея : Науковий вісник»: збірник наукових праць. - 2013. - Вип. 77. - С.83-86.

3. Європейський Союз та Україна: Стратегія відносин в контексті розширення / Інститут регіональних та євроінтеграційних досліджень «ЄвроРегіо Україна». - К. : «К.І.С.», 2013. - 206с.

4. Мікула Н. Міжтериторіальне та транскордонне співробітництво : монограсія. / Н. Мікула. - Львів : ІРД НАН України, 2004. -395 c.

5. Кухарська Н.О. Східний геоекономічний вектор України: розвиток зовнішньоекономічних відносин України з країнами СНД / Н. Кухарська // Формування ринкових відносин в Україні. - К. : НДЕІ, 2008. - №6 (85). - С. 145-152.

6. Сиденко В. Нелегкий путь к рынку Европейского Союза / В. Сиденко, А. Барановский // Зеркало недели. - 2004. - №1. $-\mathrm{C} .1,8$.

7. Crowdfunding's Potential for the Developing World [Електронний ресурс] / World Bank. - Режим доступу: http://www.funginstitute.berkeley.edu/sites/defaul/files

8. Закон України «Про стимулювання розвитку регіонів» від 8.09.2005 р. №2850-IV // Відомості Верховної Ради України (BBP). - 2005. - №51. - C. 548.

9. Забарна Е.М. Саморозвиток регіону на основі імплементації європейського досвіду в регіональну зовнішньоекономічну політику України [Електронний ресурс] / Е.М.Забарна // Економіка та суспільство - 2017. - №8. - Режим доступу: http://www.economyandsociety.in.ua/journal-8/15-stati-8/732-zabarna-e-m.

10. Кухарская Н.А. Стратегические приоритеты трансформации экономики регионов Украины: тенденции, формы, механизмы: монография / Н.А. Кухарская / Институт проблем рынка и экономико-экологических исследований НАН Украины. - Одесса: ИПРЭЭИ НАН Украины, 2010. - 519 с.

11. Шнырков А. Экономика ЕС-10: два года после вступления в Союз / А. Шнырков // Зеркало недели. - 2006. - №34 . C. 11.

12. Корольков А.Ф. ЕС: сельскохозяйственная и аграрная политика / А.Ф. Корольков // Современная Европа. - 2008. №4. - С. 90-98.

13. Герасимчук 3.В. Еколого-економічні принципи удосконалення конкурентоздатності регіонів: монографія / З.В. Герасичук, О.С. Білик. - Луцьк: Веста-друк, 2014. - 284 с.

1. Turchin, J.B., Demchyshak, R.B., \& Plazova, T.I. (2013). Istoriya mizhnarodnyh vidnosyn (vid Starodavnogo svitu do pochatku XX stolittya) [History of International Relations (from the Ancient World to the early XX century] - Lviv: Printed Lviv. University of Technology [in Ukrainian].

2. Datskiv, I.B., \& Masliy, V.V. (2013). Ukraine yak uchasnik mizhnarodnoyi investytsiynoyi liyalnosty: istorichnyy aspect [Ukraine as a member of an international investment: a historical perspective]. Gilea: Naukovyy visnyk - Gilea: Scientific Herald, 77, 83-86 [in Ukrainian].

3. Institute of Regional and Euro-Integration Studies "EvroRehioUkrayina" (2013). Evropeyskiy souz ta Ukraina: strategiya vidnosin v kontekste rozshyrennya [The EU and Ukraine: Strategies in the context of expanding]. Kyiv: «K.I.C.» [in Ukrainian].

4. Mikula, N. (2004). Mizhteritorialne ta transkordonne spivrobitnytstvo [Interterritorial and cross-border cooperation]. Lviv: IRI NAS of Ukraine [in Ukrainian].

5. Kuharska, N. (2008). Shidniy geoeconomichniy vector Ukrainy: rozvitok zovnishnoekonomichnuh vidnosyn Ukrainy z krainamy SND [East geoeconomic vector of Ukraine: development of foreign economic relations of Ukraine with the CIS] 
Formuvannja rynkovyx vidnosyn v Ukrajini - Formation of market relations in Ukraine, 6 (85), 145-152 [in Ukrainian].

6. Siedenko, V., \& Baranovsky, A. (2004). Nelegkiy put k rynku Evropeyskogo Souza [The hard way to the market of the European Union]. Zerkalo nedely. - Weekly Mirror, 1, 8. [in Russian].

7. World Bank (2013). Crowdfunding's Potential for the Developing World. funginstitute.berkeley.edu. Retrieved from https://funginstitute.berkeley.edu/publication/crowdfundings-potential-for-the-developing-world/.

8. Zakon Ukrainy "Pro stymuluvannya rozvitku regioniv" [The Law of Ukraine "On Stimulation of Regional Development"] (n.d.). zakon.rada.gov.ua. Retrieved from http://zakon.rada.gov.ua/cgi - bin/laws/main.cgi?nreg=40-15 [in Ukrainian].

9. Zabarna, E. (2017). Samorozvitok region na osnovi implementatsiy evropeyskogo dosvidu $v$ regionalnu zovnishnoekonomichnu politiku Ukrainy [Self-development of the region through the implementation of European experience in regional in foreign economic policy of Ukraine]. Ekonomika i suspilstvo - Economics and society, 8. Retrieved from http://www.economyandsociety.in.ua/journal-8/15-stati-8/732-zabarna-e-m [in Ukrainian].

10. Kuharskaya, N. (2010). Strategicheskiye prioritety transformatsiyi ekonomiky regionov Ukraine: tendentsiyi, formy, mehanizmy [Strategic priorities of economic transformation of Ukrainian regions: trends, forms, mechanism]. Odessa: Institute for Market Problems and Economic and Environmental Studies NAS of Ukraine [in Russian].

11. Shnyrkov, A. (2006). Ekonomika ES-10: dva goda posle vstupleniya v Souz. [Economy EU-10: two years after joining the Union]. Zerkalo nedely - Weekly Mirror Ukraine, 34, 11 [in Russian].

12. Sorolkov, A. (2008). ES: Selskohozyaystvennaya i agrarnaya polytyka [EU: agricultural and agrarian policy]. Sovremennaya Evropa. - Modern Europe, 4, 90-98 [in Russian].

13. Gerasymchuk, Z.V., \& Bilyk, O.S. (2014). Ekologo-ekonomichni printsypy pokratzhennya konkurentozdatnosty regioniv [Environmental and economic principles of improving the region competitiveness]. Lutsk : Vezha-Drug [in Ukrainian].

E.M. Забарна, д-р екон. наук, професор, завідувач кафедри економічних систем і управління інноваційним розвитком, Одеський національний політехнічний університет (м. Одеса, Україна)

Periональна складова процесу інтеграції України в Європейський простір

В статті досліджено комплекс проблем, пов'язаний із вступом України до європейського простору з урахуванням можливостей потенційного розвитку регіонів. Проаналізована логістика експортно-імпортних операцій з країнами Європи в регіональному вимірі. Запропоновано заходи щодо активізації процесів євроінтеграції України.

Ключові слова: регіон, європейський простір, інтеграція, Україна-ЄС, соціально-економічний розвиток.

э.н. Забарная, д-р экон. наук, профессор, заведующая кафедрой экономических систем и управления инновационным развитием, Одесский национальный политехнический университет (г. Одесса, Укоаина)

Региональная составляющая процесса интеграции Украины в Европейское пространство

В статье исследован комплекс проблем, связанный с вступлением Украины в европейское пространство с учетом возможностей потенциального развития регионов. Проанализирована логистика экспортно-импортных операций со странами Европы в региональном разрезе. Предложены мероприятия по активизации процессов евроинтеграции Украины.

Ключевые слова: регион, европейское пространство, интеграция, Украины-ЕС, социально-экономическое развитие.

Отримано 21.03.2017 p. 